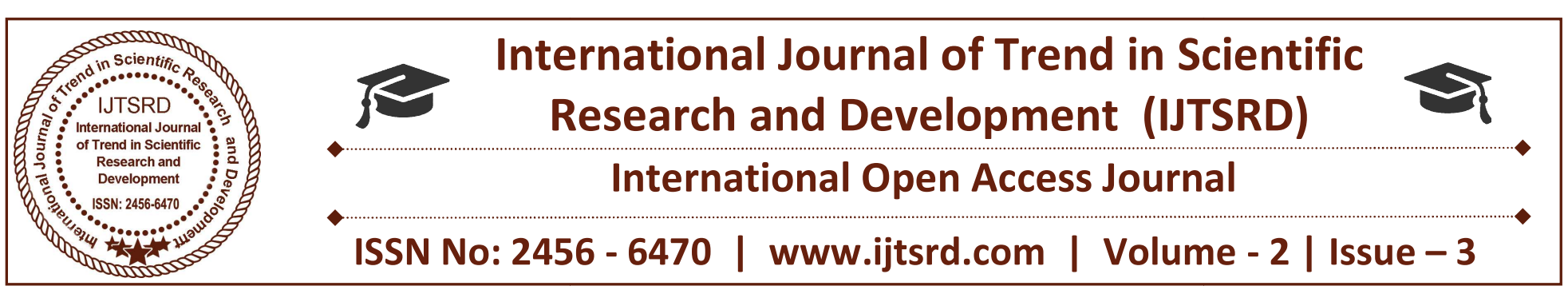

\title{
A Modern and Experimental Study on stabilization of Marine Clay by using coir fibre for Foundation
}

\author{
Harish Parimi \\ Assistant Professor, Department of \\ Civil Engineering, \\ Pydah College of Engineering, \\ Visakhapatnam, India
}

\author{
Lavanya Punnam \\ Assistant Professor, Department of \\ Civil Engineering, \\ Nadimpalli Satyanarayana Raju \\ Institute of Technology, \\ Visakhapatnam, India
}

\author{
Haragopal Peddinti \\ Assistant Professor, Department of \\ Civil Engineering, \\ Nadimpalli Satyanarayana Raju \\ Institute of Technology, \\ Visakhapatnam, India
}

\begin{abstract}
Here, in this project, marine soil stabilization has been done with the help of randomly distributed polypropylene fibres obtained from waste materials. The improvement in the shear strength parameters has been stressed upon and comparative studies have been carried out using different methods of shear resistance measurement. Reinforcement of soils with natural coir is potentially an effective technique for increasing soil strength. Coir fibre is a degradable material. coir fibre is mixing where coir fibre is not degradable. The marine clay stabilization mostly used chemicals and other types of ashes, this study have been carried out using with coir fibre material. The present investigation aims to explore the performance of different percentages coir fibre material reinforced with marine clay.
\end{abstract}

Keywords: Coir Fibre, Marine Clay, Shear Strength

\section{INTRODUCTION}

For any land-based structure, the foundation is very important and has to be strong to support the entire structure. In order for the foundation to be strong, the soil around it plays a very critical role. So, to work with soils, we need to have proper knowledge about their properties and factors which affect their behavior. The process of soil stabilization helps to achieve the required properties in a soil needed for the construction work. A land based.

Structure of any type is only as strong as its foundation. For that reason, soil is a critical element influencing the success of a construction project. Soil is either part of the foundation or one of the raw materials used in the construction process. Therefore, understanding the engineering properties of soil is critical to obtain strength and economic performance. Soil stabilization is the process of maximizing the suitability of soil for a given construction purpose.

Reinforcement of soils with natural coir is potentially an effective technique for increasing soil strength. In recent year, this technique has been suggested for a variety of geotechnical applications ranging from retaining structures and earth embankments to sub grade stabilization beneath footing and pavements. Research of different reinforcement and materials has been conducted by several investigations. However, the amount of information available on randomly oriented fibre reinforcement is still limited.

\section{NEED OF PRESENT STUDY}

Soil properties vary a great deal and construction of structures depends a lot on the bearing capacity of the soil, hence, we need to stabilize the soil which makes it easier to predict the load bearing capacity of the soil and even improve the load bearing capacity. The gradation of the soil is also a very important property to keep in mind while working with soils. The soils may be well-graded which is desirable as it has less number of voids or uniformly graded which though sounds stable but has more voids. Thus, it is better to mix different types of soils together to 
improve the soil strength properties. It is very expensive to replace the inferior soil entirely soil and hence, soil stabilization is the thing to look for $\mathbf{i B}$. these cases

\section{OBJECTIVES OF PRESENT STUDY}

The objectives of the present study are as follows.

- To evaluate the performance of Marine Clay when treated with Coir Fibre as admixture.

- To study the performance of treated marine clay as foundation beds

\section{LABORATORY EXPERIMENTATION}

\section{A. Marine Clay}

The marine clay used as the foundation soil in this study is of typical soft clay. The marine clay was collected at a depth of $0.40 \mathrm{~m}$ to $1.00 \mathrm{~m}$ from the existing ground level.

\section{Physical properties of marine clay}

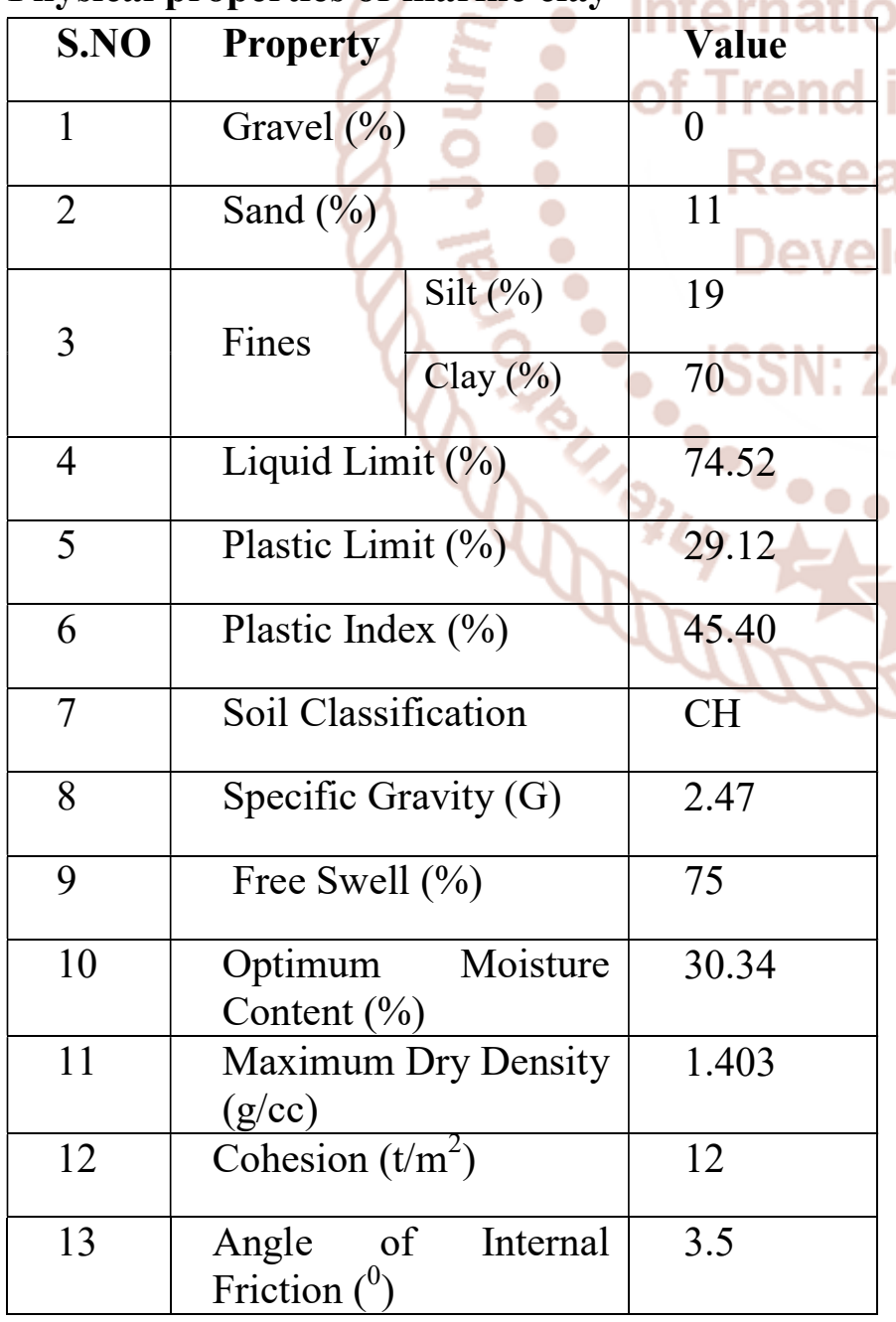

\section{Chemical Properties coir fibre}

Chemical properties of coir fibre are mixing some amount of ash. The chemicals are lignin, cellulose, hemi-cellulose, pectin's and related compound, water soluble and ash.

\section{Chemical properties of coir fibre}

\begin{tabular}{|c|c|c|}
\hline S.No & $\begin{array}{l}\text { Chemical } \\
\text { Composition }\end{array}$ & Value \\
\hline al Jalur & Lignin (\%) & 45.84 \\
\hline SCI2 & Cellulose (\%) & 43.44 \\
\hline Cit al 30 & Hemi-cellulose (\%) & 00.25 \\
\hline PItIe $_{4}$ & $\begin{array}{l}\text { Pectin's and related } \\
\text { compound }(\%)\end{array}$ & 03.00 \\
\hline $56-6450$ & Water soluble (\%) & 05.25 \\
\hline $\begin{array}{r}60 \\
\end{array}$ & Ash (\%) & 02.22 \\
\hline
\end{tabular}

\section{Tests conducted}

The soil was initially air dried prior to the testing. The tests were conducted in the laboratory on the marine clay to study the behavior of the marine clay, when it was untreated and also treated with fly ash and quarry dust for the model foundation soil bed.

- Atterberg limits

- Compaction Test

- Free swell (FS)

- CBR Test

- Tri-axial Test

- Unconfined Compression Test

- Specific gravity test

- Static Plate Load Test 


\section{RESULTS}

Details of the laboratory experimentation carried-out with different combinations of materials have been discussed in the previous chapter including the laboratory static plate load tests on untreated and treated marine clay model foundation beds. In this chapter a detailed discussion on the results obtained from various laboratory tests are presented including the results of laboratory static plate load tests on untreated and treated marine clay model foundation beds. In the laboratory, index tests, swell tests, strength tests were conducted by using different percentages of coir fibre with a view to determine the optimum percentages of coir fibre. The static plate load tests were conducted on untreated and treated marine clay sub grade foundation beds. The effect of addition of coir fibre to the marine clay, on compaction, CBR properties, Atterberg's limits, swell properties, and strength properties, were discussed

\section{Compaction Test Results for Untreated Marine} Clay

\begin{tabular}{|l|l|l|}
\hline Mix Proportion & $\begin{array}{l}\text { Water Content } \\
(\mathbf{\%})\end{array}$ & $\begin{array}{l}\text { Dry Density } \\
\text { (g/cc) }\end{array}$ \\
\hline \multirow{4}{*}{ Marine Clay } & 29.23 & 1.337 \\
\cline { 2 - 3 } & 32.45 & 1.345 \\
\cline { 2 - 3 } & $\mathbf{3 5 . 3 4}$ & $\mathbf{1 . 3 7 3}$ \\
\cline { 2 - 3 } & 37.12 & 1.354 \\
\cline { 2 - 3 } & 39.12 & 1.326 \\
\hline
\end{tabular}

Compaction Test Results for Marine Clay Treated with Percentage Variation of Coir Fibre

\begin{tabular}{|l|l|l|}
\hline Mix Proportion & OMC (\%) & $\begin{array}{l}\text { MDD } \\
\text { (g/cc) }\end{array}$ \\
\hline $\begin{array}{l}100 \% \text { Marine } \\
\text { clay+0\% coir fibre }\end{array}$ & 35.34 & 1.373 \\
\hline $\begin{array}{l}99.75 \% \text { Marine clay } \\
+0.25 \% \text { coir fibre }\end{array}$ & 32.37 & 1.408 \\
\hline $\begin{array}{l}99.5 \% \text { Marine clay } \\
+0.5 \% \text { coir fibre }\end{array}$ & 30.77 & 1.435 \\
\hline $\begin{array}{l}\mathbf{9 9 . 2 5 \%} \text { Marine clay } \\
+\mathbf{0 . 7 5 \% c o i r ~ f i b r e ~}\end{array}$ & $\mathbf{2 7 . 3 4}$ & $\mathbf{1 . 4 8 2}$ \\
\hline $\begin{array}{l}\text { 99\% } \\
\text { Marineclay+1.0\% coir } \\
\text { fibre }\end{array}$ & 24.34 & 1.475 \\
\hline
\end{tabular}

\section{Compaction curves for different percentages of} marine clay treated with various percentages of coir fibre

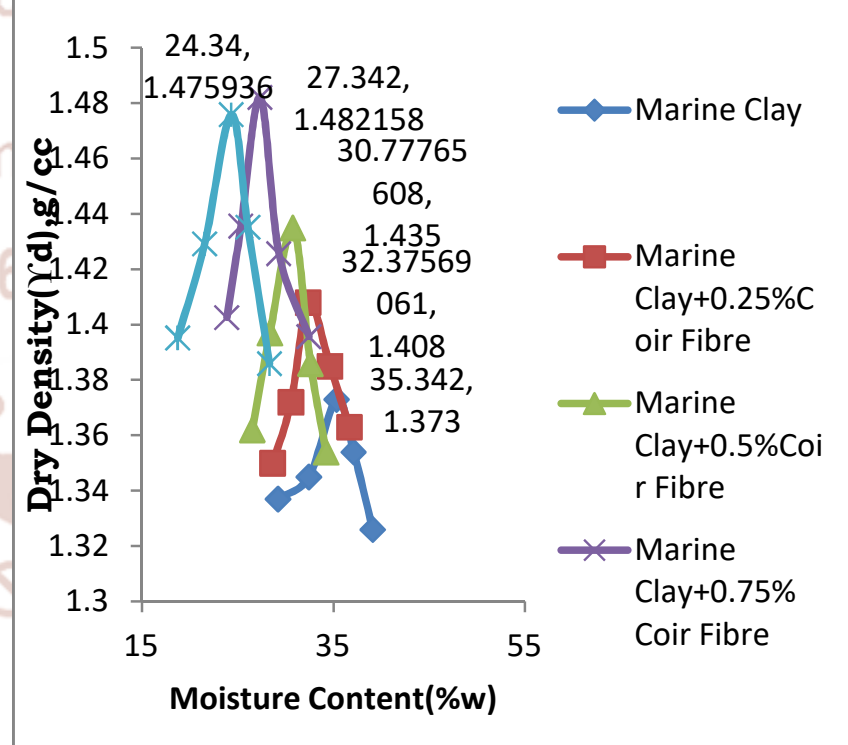


International Journal of Trend in Scientific Research and Development (IJTSRD) ISSN: 2456-6470

CBR, UCC and Tri-Axial test values of marine clay treated with various percentages of coir fibre

\begin{tabular}{|l|l|l|l|l|c|}
\hline $\begin{array}{l}\text { Mix } \\
\text { proportion }\end{array}$ & $\begin{array}{l}\text { \% Variation } \\
\text { of Coir Fibre }\end{array}$ & $\begin{array}{l}\text { Soaked } \\
\text { CBR }\end{array}$ & $\begin{array}{l}\text { UCC } \\
\left(\mathbf{k N} / \mathbf{m}^{2}\right)\end{array}$ & $\begin{array}{l}\text { Cohesion } \\
\mathbf{c} \\
\left(\mathbf{k N} / \mathbf{m}^{2}\right)\end{array}$ & $\begin{array}{l}\text { Angle } \\
\text { internal } \\
\text { Friction( } \boldsymbol{(})\end{array}$ \\
\hline Marine clay & 0 & 0.895 & 69.4 & 12 & 3.5 \\
\hline $\begin{array}{l}99.75 \% \text { Marine } \\
\text { clay }\end{array}$ & 0.25 & 3.137 & 79.71 & 10.5 & 4.2 \\
\hline $\begin{array}{l}99.5 \% \text { Marine } \\
\text { clay }\end{array}$ & 0.5 & 3.361 & 94.9 & 8.43 & 5.2 \\
\hline $\begin{array}{l}\mathbf{9 9 . 2 5 \%} \\
\text { Marine clay }\end{array}$ & $\mathbf{0 . 7 5}$ & $\mathbf{3 . 8 0 9}$ & $\mathbf{1 2 8}$ & $\mathbf{7 . 8 5}$ & $\mathbf{5 . 8}$ \\
\hline $\begin{array}{l}99 \% \\
\text { clay Marine }\end{array}$ & 1.0 & 3.495 & 118 & 5.67 & 6.7 \\
\hline
\end{tabular}

Properties of untreated marine clay and marine clay treated with coir fibre

\begin{tabular}{|c|c|c|c|}
\hline Sl.no & 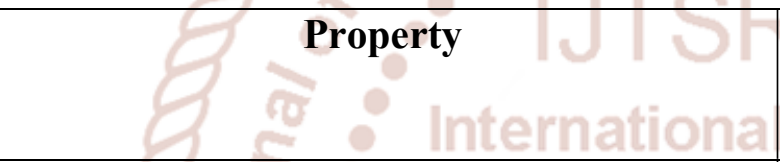 & $\begin{array}{l}\text { Untreated Marine } \\
\text { Clay } \\
\text { Journal }\end{array}$ & $\begin{array}{l}0.75 \% \text { Coir Fibre } \\
\text { Treated } \\
\text { Marine Clay }\end{array}$ \\
\hline 1. & $\begin{array}{l}\text { Atterberg limits } \\
\text { Liquid limit }(\%) \\
\text { Plastic limit }(\%) \\
\text { Plasticity index }(\%)\end{array}$ & $\begin{array}{l}\mathbf{7 4 . 5 2} \\
\mathbf{2 9 . 1 2} \\
\mathbf{4 5 . 4 0}\end{array}$ & $\begin{array}{l}60.07 \\
33.09 \\
26.98\end{array}$ \\
\hline 2. & $\begin{array}{l}\text { Compaction properties } \\
\text { Optimum Moisture Content, (\%) } \\
\text { Maximum Dry Density, (g/cc) SSN: } 2456 \text {. }\end{array}$ & $\begin{array}{ll}\text { ment } \\
\mathbf{3 0 . 3 4} \\
\mathbf{1 . 4 0 3}\end{array}$ & $\begin{array}{l}27.42 \\
1.482\end{array}$ \\
\hline 3. & Specific Gravity (G) & 2.47 & 2.57 \\
\hline 4. & C.B.R (\%) & 1.07 & 3.809 \\
\hline 5. & Free swell (\%) & 75 & 45.76 \\
\hline 6. & $\begin{array}{l}\text { Shear Strength Parameters } \\
\text { Cohesion }\left(\mathrm{t} / \mathrm{m}^{2}\right) \\
\text { Angle of internal friction }\left({ }^{\mathbf{0}}\right)\end{array}$ & $\begin{array}{l}12 \\
3.5\end{array}$ & $\begin{array}{c}7.25 \\
5.8\end{array}$ \\
\hline 7 & $\mathrm{UCC}\left(\mathrm{kN} / \mathrm{m}^{2}\right)$ & 69.4 & 128 \\
\hline
\end{tabular}

\section{CONCLUSIONS}

1. It was noticed that when the Marine Clay was treated with $0.75 \%$ coir fibre the liquidity limit and plasticity index of Marine Clay has been decreased by $19.39 \%, 41.25 \%$ when compared

2. It was noticed that when the Marine Clay was treated with $0.75 \%$ coir fibre the free swell is decreased by $38.98 \%$ respectively when compared with untreated Marine Clay. with untreated Marine Clay. 
3. It was noticed from laboratory plate load test that the total deformations at ultimate load carrying capacity of treated model foundation bed has decreased by $45.0 \%$ at OMC when compared to the untreated Marine Clay.

4. It was noticed from laboratory plate load test that ultimate load bearing capacity of the treated Marine Clay has increased by $142.49 \%$ when compared to the un treated Marine Clay at OMC when compared to the untreated Marine Clay.

\section{REFERENCES}

1. S. A. Naeini and s. M. Sadjadi ,(2008), , effect of waste polymer materials on shear strength of Unsaturated Clays", EJGE Journal, Vol 13, Bund $\mathrm{k},(1-12)$.

2. Yetimoglu, T., Inanir, M., Inanir, O.E., 2005. A study on bearing capacity of randomly distributed fibre-reinforced sand fills overlying soft clay. Geotextiles and Geomembranes 23 (2), 174-183.

3. Chaosheng Tang, Bin Shi, Wei Gao, Fengjun Chen, Yi Cai, 2006. Strength and mechanical behavior of short polypropylene fibre reinforced and cement stabilized clayey soil. Geotextiles and Geomembranes 25 (2007) 194-202.

4. Mahmood R. Abdi, Ali Parsapajouh, and Mohammad A. Arjomand,(2008)," Effects of Random Fibre Inclusion on Consolidation, Hydraulic Conductivity, Swelling, Shrinkage Limit and Desiccation Cracking of Clays", International Journal of Civil Engineering, Vol. 6, No. 4, (284-292).

5. Consoli, N. C., Prietto, P. D. M. and Ulbrich, L. A. (1999). "The behavior of a fibre-reinforced cemented soil.', Ground

London, 3(1), 21-30.

6. IS 2720 - part (xiii) 1980-87

7. The need for soil stabilization, April 9, 2011 by Ana

[online].Availableat: $<$ http://www.contracostaland scaping.com/the-need-for-soil-stabilization/>

8. Methods of soil stabilization, December 24, 2010 [online] Available at $<$ http://www.engineeringtraining.tpub.com/140 70/css/14070_424.htm >

9. Prof. Krishna Reddy, UIC, 2008, Engineering Properties of Soils Based on Laboratory Testing.
10. Understanding the Basics of Soil Stabilization: An Overview of Material and Techniques [online] Available at : <http://www.cat.com >

11. Punmia B.C. 2007, "Soil Mechanics \& Foundations" Laxmi Publications

12. Yadav Parit, Meena Kuldeep Kumar, (2011)” A comparative study in soil plasticity of Hall area and lecture complex area of NIT Rourkela" B.tech thesis, NIT,Rourkela.

13. IS: 2720(Part 2), 1973 Methods of Test for Soils, Determination of water content.

14. 14. IS 2720(III/SEC-I): 1980 Methods of Test for Soils, Determination of specific gravity.

15. IS 2720(VII):1980 Methods of Test for Soils, Determination of water content dry density relation using light compaction.

16. IS 2720(XIII):1986 Methods of Test for Soils, direct shear test

17. IS 2720(X):1991 Methods of Test for Soils, determination of unconfined compression test.

18. IS 2720(IV):1985 Methods of Test for Soils, determination of grain size analysis.

19. Ground Improvement Techniques, December 18, 2008 [online] Available at: < http://www.engineeringcivil.com >

20. Das B.M, 1992, Fundamentals of Soil Dynamics, Elsevier.

21. Vidal.H. (1969). The Principle of Reinforced Earth, Highway Research Board, Washington, DC, Highway Research Record, No. 282, pp.116

22. Gray, D. H. \&Ohashi, H. (1983). Mechanics of fibre reinforcement in sand. Journal of Geotechnical Engineering, ASCE, 109, No. $3,335-353$. 